\title{
New species of Eleocharis (family Cyperaceae) in Australia
}

\author{
Karen L. Wilson \\ National Herbarium of New South Wales, Royal Botanic Gardens, Mrs Macquaries Road, \\ Sydney NSW 2000, Australia
}

\begin{abstract}
Four new species in Eleocharis R.Br. subgenus Limnochloa (P.Beauv. ex T.Lestib.) Torr. are described: Eleocharis jacobsiana, E. rivalis, E. sanguinolenta and E. triquetra. All of these species are from tropical Australia.
\end{abstract}

\section{Introduction}

The genus Eleocharis includes about 250 species (Govaerts et al.2007), growing in at least seasonally wet habitats - the perennial species commonly in permanently wet places mainly in tropical and warm-temperate parts of the world. There is a concentration of species in the Americas (at least 145 species, in all four subgenera currently recognised, fide González-Elizondo and Tena-Flores 2000). There are 34 species native to Australia and three species naturalised.

Since Blake (1939) published his revision of Australian species, there has been much greater access to tropical regions for fieldwork and, as a result, four new species in Eleocharis subgenus Limnochloa (P.Beauv. ex T.Lestib.) Torr. (previously known as series Mutatae Svenson) are here recognised. Some of that fieldwork has been undertaken by me over the last thirty years, often in company with my late colleague Dr Surrey Jacobs, who developed an encyclopedic knowledge of Australia's wetland plants, grasses and chenopods over four decades. I have great pleasure in naming one of the new species after him.

These four new species all belong to the informal Clade A in Hinchliff and Roalson's phylogenetic molecular analysis of subgenus Limnochloa (2009). Further discussion of these and the other Australasian species in this genus is included in another manuscript currently being prepared. 
The four species share the features common to all species in this genus: the leaves are reduced to basal sheaths; the inflorescence is reduced to a single spikelet; and the stylebase is persistent on the achene, which has a number of perianth bristles persistent around its base (Fig 1). As in all members of subgenus Limnochloa, the glumes (floral bracts) have numerous fine longitudinal nerves on their sides as well as the central midnerve, which is often not distinct abaxially but is more distinct on the adaxial surface.

The culms of these four species differ in their internal structure. The central part of the culm in three species is pluritubulose, i.e. with several to many longitudinal septa, each with small cross-septa. When such culms are dried, these partial transverse septa are commonly not obvious externally. Such culms are described by Cowie (2000, fig. 58) and Hinchliff and Roalson (2009) as spongy with an extensive network of incomplete transverse and longitudinal septa. The fourth species, E. jacobsiana, has unitubulose culms, i.e. there are complete transverse septa running right across the internal diameter of the culm but without any subdividing longitudinal septa (as found in, e.g., E. sphacelata R.Br.), but this new species also has a single vascular strand running longitudinally down the centre of the culm. This corresponds to Cowie and Hinchliff and Roalson's transversely septate culm with a central vascular bundle, and is very unusual in the genus. The only other species with a structure like this is the Guayanan species E. endounifascis, recently described by Hinchliff et al. (2010). The terms 'pluritubulose' and 'unitubulose' have not been used to describe sedge morphology before but have frequently been used to describe the similar internal
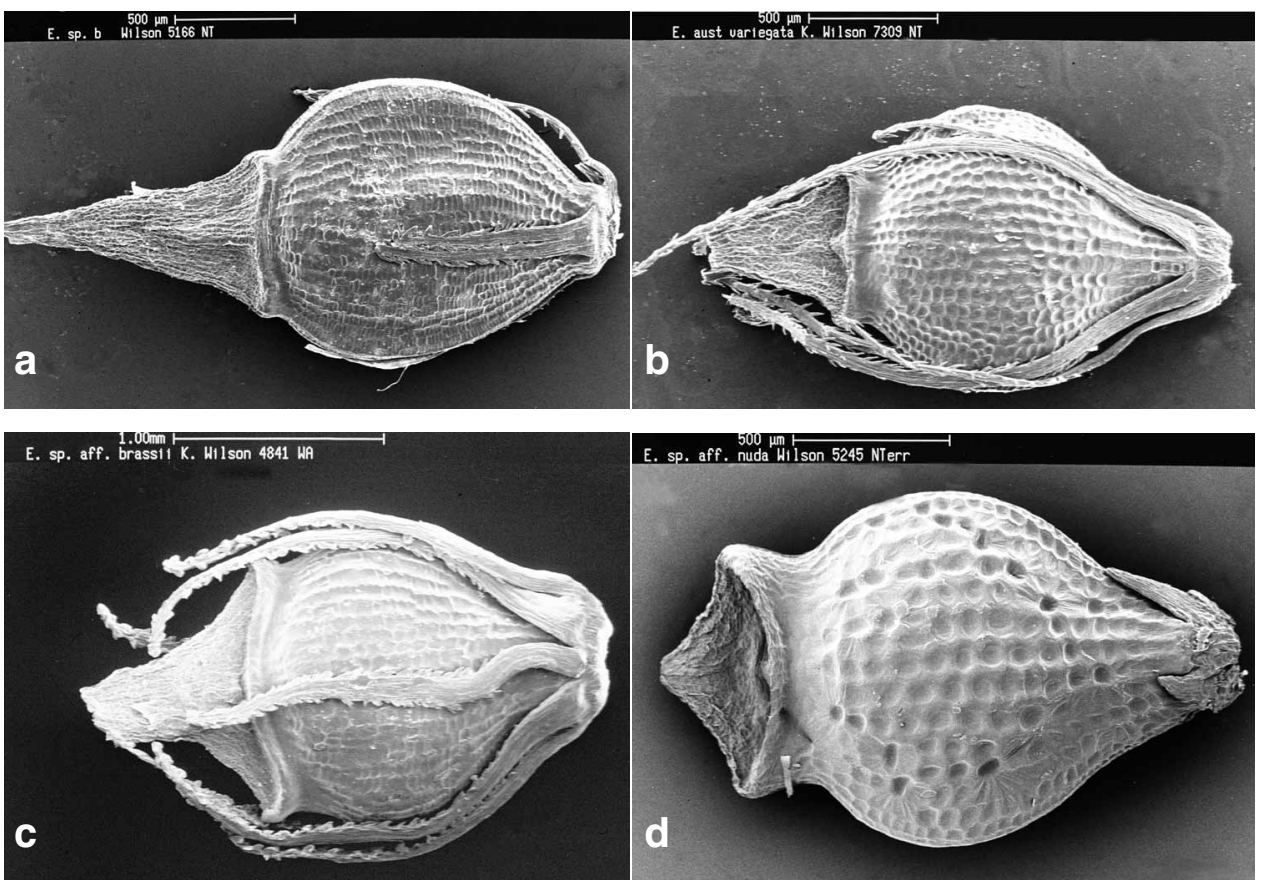

Fig. 1. Achene and perianth bristles of: a, Eleocharis jacobsiana (K.L. Wilson 5166); b, Eleocharis rivalis (K.L. Wilson 7309); c, Eleocharis sanguinolenta (K.L. Wilson 4841) and d, Eleocharis triquetra (K.L. Wilson 5245) with reduced perianth bristles. 
structure of the culms of so-called septate Juncus species (e.g., by Buchenau (1890), Snogerup (1980), Fernández-Carvajal et al. (1989, figs 44-47), Wilson et al. (1993), Kirschner (2002, fig. 36)).

Tubers are infrequently collected with specimens of Eleocharis. It is not clear whether this is because they are produced by only a few species, perhaps only in certain habitats or under certain growth conditions, or because the tubers are delicately attached to the plant and therefore readily broken off when collections are made. I have seen them in the Northern Territory in E. dulcis (Burm.f.) Trin. ex Henschel, E. sundaica J.H.Kern and E. jacobsiana.

\section{Description of new species}

\section{Eleocharis jacobsiana K.L.Wilson, sp. nov.}

A speciebus omnibus australiensibus subgeneris Limnochloae culmis transversaliter septatis, filamento vasculari singulari longitudinale centrali, differt.

Type: Northern Territory: Darwin \& Gulf: Leachs Lagoon, c. $45 \mathrm{~km}$ S of Katherine, S of King River, K.L. Wilson 7541 \& S.W.L. Jacobs, 6 Jun 1987; holo NSW 196818; iso DNA, NSW 867244. Figure 2.

Slender annual or perennial, with slender stolons and occasional small tubers to c. $5 \mathrm{~mm}$ diam., frequently with numerous filiform sterile culms to c. $25 \mathrm{~cm}$ long. Fertile culms erect, tufted, terete, yellow-green, unitubulose with numerous transverse septa but only 1 delicate longitudinal vascular strand (easily broken and therefore often overlooked when the culm is split), smooth or with transverse septa faintly visible when dry, 40-80 cm high, 0.8-2.2 mm diam. Upper leaf sheath green to pale yellowbrown, membranous, very fragile so ripping easily, with strongly oblique apex not differently coloured or thickened, tight around the culm. Spikelet more or less terete in cross-section, from slightly narrower to slightly broader in diameter than the culm, $1.2-2.0 \mathrm{~cm}$ long, $1.5-2.0 \mathrm{~mm}$ diam. Glumes numerous, striate, with a fairly indistinct midnerve abaxially, flat to slightly concave when dry, apex broad-acute to acute, with hyaline margin c. $0.2 \mathrm{~mm}$ wide, pale yellow-brown, 3.3-4.0 mm long, 1.4-2.0 mm wide; exposed portion of glume longer than broad, 1.5-3 mm long. Perianth bristles $4-7$, subequal in length, $1 / 5^{-1 / 2}$ as long as achene body or occasionally equalling it, pale brown, with weak retrorse setae. Stamens 3, occasionally 2; anthers (excluding apical appendage) $1.1-1.8 \mathrm{~mm}$ long; appendage no more than $0.1 \mathrm{~mm}$ long. Style $2-3$-fid; persistent style-base flattened, long-triangular, $1 / 3-1 / 2$ as long as achene, $1 / 2-2 / 3$ as wide as achene. Achene rarely produced, biconvex, narrow-obovate to broad-obovate in outline, margins not ribbed, without a distinct neck but with an upturned horizontal annulus, achene pale yellow-brown to very dark brown, 1.3-1.6 mm long, 1.0-1.2 mm diam., epidermal cells minutely transversely linear-oblong, in 15-18 more or less welldefined columns. Figure 1a.

Distribution and ecology: widespread in the wet/dry tropics of northern Australia; from the western Kimberley region of Western Australia, to the Victoria River Region, the northern Tanami (Ian Cowie, pers. comm.) and the Darwin and Gulf Region of the Northern Territory. There is one specimen from near Weipa on Cape York in Queensland; it is immature and vegetative but has the characteristic culm structure and numerous filiform culms of this taxon. Figure 3. 


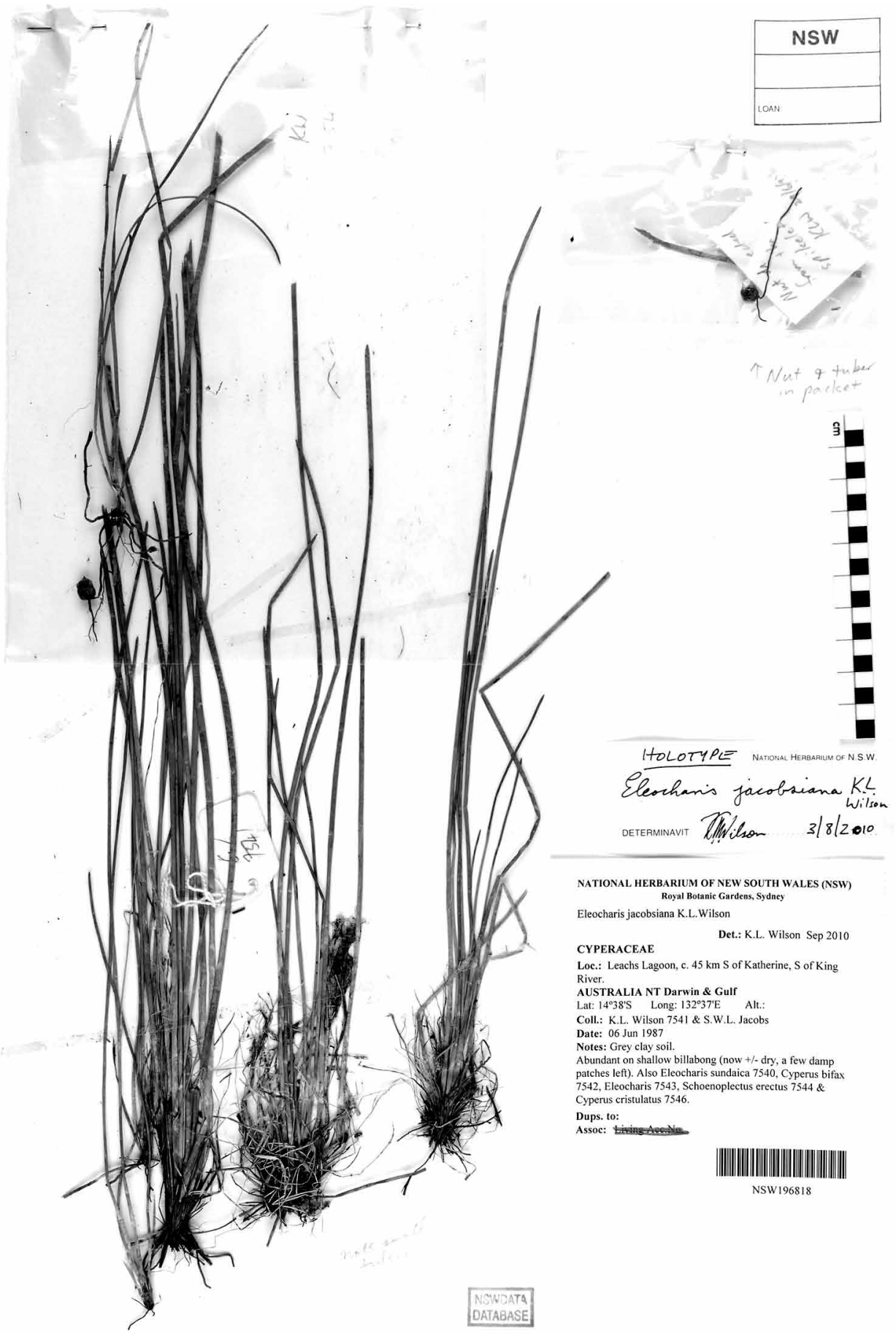

Fig. 2. Holotype of Eleocharis jacobsiana. 
In clear water 5-100 cm deep in small streams (commonly plants are mostly submerged and with numerous slender sterile culms present) and in seasonally drier situations around billabongs and in swamps, in sandy or silty soil. It has been collected with or near E. brassii S.T.Blake, E. dulcis, E. nuda C.B.Clarke, E. rivalis, and E. sundaica.

Notes: the type specimen is over-mature, collected from a rapidly drying lagoon, but it is considered to be the best choice for type since it has both fruit and tubers whereas nearly all other specimens, while being in much better condition, are either sterile or have immature spikelets and lack tubers.

This taxon was referred to as 'Eleocharis (Coonjimba Billabong entity)' by Cowie (2000, fig. 58) and Hinchliff and Roalson (2009).

It is unique amongst Australian species of subgenus Limnochloa in having unitubulose culms as well as a single vascular strand running longitudinally down the centre of the culm. The only other species like this, the Guayanan species E. endounifascis, falls in Clade B in the analysis by Hinchliff et al. (2010), suggesting that the culm structure has evolved independently in these two species.

E. jacobsiana is similar to E. ochrostachys Steud. and E. nuda in having slender, terete culms but it differs from both in its internal culm structure and in achene and perianth bristle features. Also, its glumes have a narrower hyaline margin than those of E. ochrostachys. Slender plants of E. dulcis may look superficially similar to E. jacobsiana, but their unitubulose culms lack the single longitudinal strand down the centre of the culm.

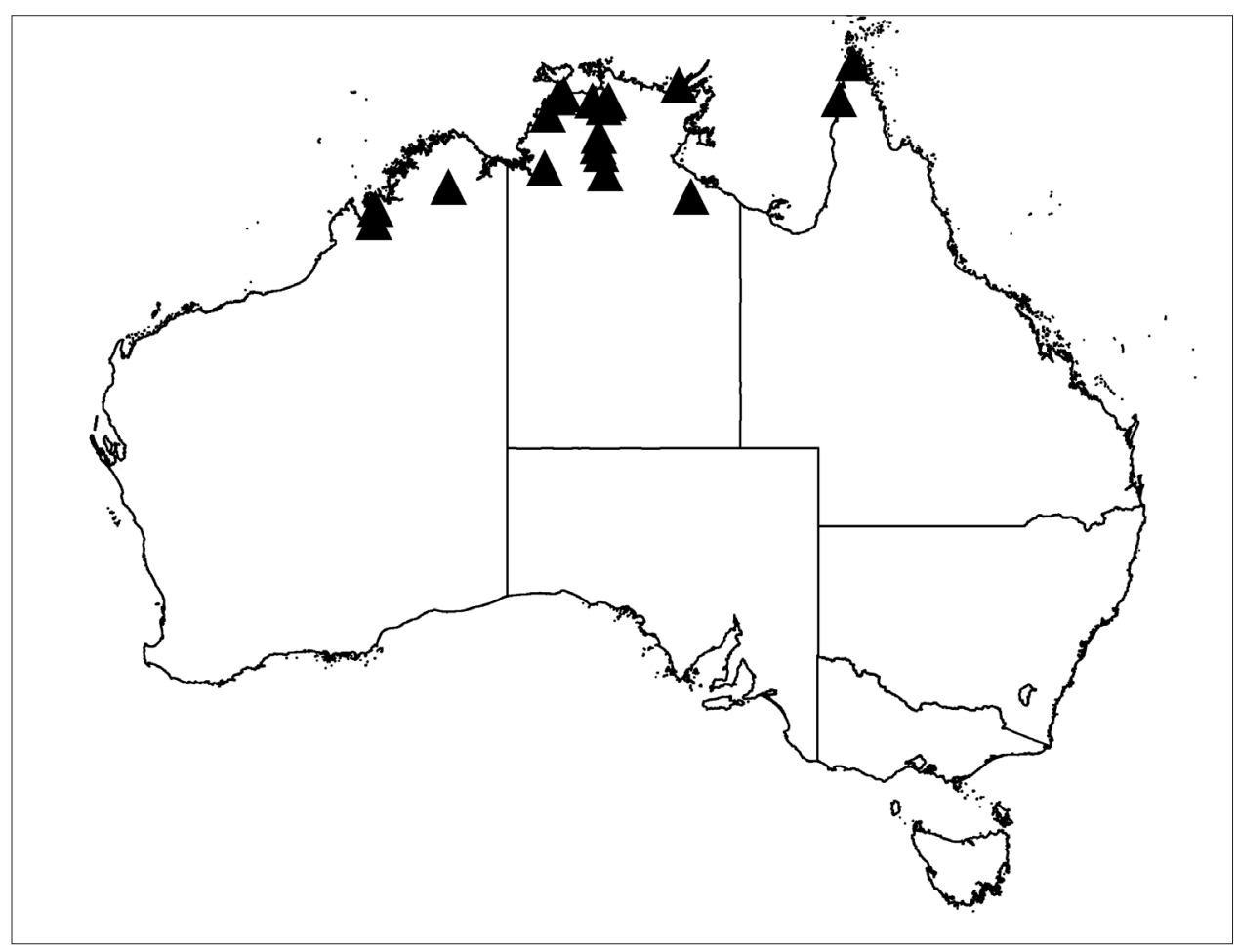

Fig. 3. Distribution of Eleocharis jacobsiana in Australia. 
Etymology: the species is named in honour of my late colleague Dr Surrey Wilfrid Laurence Jacobs (1946-2009), who contributed so much during his career to knowledge of the systematics and phylogeny of Australian waterplants, grasses and chenopods. With our common interest in plants growing in wet places, Surrey and I undertook numerous field trips together, including the one on which the types of this species and E. rivalis were collected.

Selected specimens examined: Western Australia: Dampier: 'Meda', E of Derby, S.W.L. Jacobs 4280, 26 May 1982 (NSW). Fitzgerald: 'Gibb River' - Wyndham road, S.W.L. Jacobs 4415, 4 Jun 1982 (NSW); c. 13 km SE of 'Kimbalton' Homestead, Oobagooma road, S.W.L. Jacobs 5745 \& P.G. Wilson, 26 May 1988 (NSW).

Northern Territory: Darwin \& Gulf: Nitmiluk National Park, near source of Fergusson River, I.D. Cowie $9545 \&$ A. Gibbons, 28 Mar 2002 (DNA, NSW); Sturt Plateau, Wyworrie Station, SW of Mataranka, I.D. Cowie 9339, 31 May 2001 (DNA, NSW); Katherine Gorge National Park, L. Craven 6731, 7 Apr 1981 (CANB, DNA); Wurrmalmirr Creek, Elcho Island, P.K. Latz 6112, 5 July 1975 (DNA); Winmurra Billabong, N.T. Sanderson s.n., 2 Apr 1980 (NSW284832, NSW284833), J.T. Waterhouse 10142, 20 Jun 1980 (NSW); 12 km NE of Gunn Point road on track to Melacca Swamp, K.L. Wilson 5084, 3 May 1983 (NSW); Kakadu Highway crossing of Nourlangie Creek, K.L. Wilson 7419, 26 May 1987 (NSW); Wirnmuyurr [Winmurra] Billabong, Jabiluka Lease, K.L. Wilson 7459, 29 May 1987 (NSW); Knuckeys Lagoon, Berrimah, K.L. Wilson 7491, 1 Jun 1987 (NSW196758); Dry Lake, Wagait Reserve, K.L. Wilson 7510, 3 June 1987 (NSW); Katherine Gorge, above Lily Pond, K.L. Wilson 7532, 5 Jun 1987 (NSW). Victoria River: Bradshaw Field Training Area, headwaters of Little Fitzmaurice River, I.D. Cowie \& B.M. Stuckey 11538, 3 Apr 2007 (DNA, NSW).

Queensland: Cook: Botchet Swamp, near Weipa, B. Herbert s.n., 24 Sep 1994 (NSW 367034).

\section{Eleocharis rivalis K.L.Wilson, sp. nov.}

$\mathrm{Ab}$ speciebus omnibus australiensibus gracilibus subgeneris Limnochloae culmis teretibus pluritubulosis, culmis sterilibus filiformibus deficientibus, collo achenii brevi sed manifesto, cellulis epidermalibus achenii isodiametricis, setis perigonialibus quam acheniis brevioribus, differt.

Type: NORTHERN TERRITORY: Darwin \& Gulf: Georgetown Billabong, Magela Creek, E of Ranger Mine, K.L. Wilson 7324, S.W.L.. Jacobs \& G.R. Sainty, 21 May 1987; holo NSW 206416; iso DNA, K. Figure 4.

Slender annual or perennial with slender stolons, without tubers so far as known. Culms erect, tufted, terete, mid-yellow-green, pluritubulose (but with only a few longitudinal strands), smooth or with incomplete transverse septa occasionally faintly visible when dry, 20-50 cm high, 0.5-1.2 $\mathrm{mm}$ diam. Upper leaf sheath membranous, more or less tight around the culm (looser near apex), pale brown above, reddish towards base, with strongly oblique apex not thickened or differently coloured. Spikelet more or less terete in cross-section, as broad as to slightly broader than the culm, $1.0-2.0 \mathrm{~cm}$ long, 1.3-2.0 mm diam. Glumes numerous, striate, with a fairly distinct midnerve, flat to slightly convex when dry, apex broad-acute to acute, with broad hyaline margin widest near apex (0.2-0.5 mm wide), pale yellow-brown, 2.5-3.6 mm long, 1.2-1.7(-2.0) $\mathrm{mm}$ broad; exposed portion of glume longer than broad, 2-4 $\mathrm{mm}$ long.

Perianth bristles 6 or 7 , usually 3 shorter than the rest, 3/4-2 times as long as the achene body, pale yellow-brown, with regularly retrorse setae. Stamens 2; anthers (excluding 
apical appendage) $0.3-1.1 \mathrm{~mm}$ long; appendage no more than $0.1 \mathrm{~mm}$ long. Style 2-fid; persistent style-base flattened, triangular, $(1 / 3-)^{1 / 2}-2 / 3$ as long as achene, $1 / 2-2 / 3$ as broad as achene. Achene biconvex, obovate in outline, margins ribbed, with short but distinct neck and with the annulus horizontal and upturned, achene yellow-brown to redbrown, $1.2-1.8 \mathrm{~mm}$ long, $0.9-1.3 \mathrm{~mm}$ diam., epidermal cells isodiametric, pitted, in 12-18 more or less distinct columns. Figure $1 \mathrm{~b}$.

Distribution and ecology: Kimberley Region of Western Australia, Victoria River and Darwin and Gulf Regions of Northern Territory, and the Cook Region of Queensland. It may occur in northwestern Queensland. Figure 5.

Grows in and around streams and billabongs, on sandy soil; often found partly submerged in clear, running water to about $15 \mathrm{~cm}$ depth in shallow streams with just the upper culms and spikelets floating on the surface. The specimen $K L W$ 7309, for example, was collected from the water of Barramundie Creek while KLW 7310 was growing on the bank of the stream. It has been collected growing with E. jacobsiana and E. ochrostachys Steud., usually along small, clear streams associated with sandstone gorges. It differs from E. jacobsiana in having slightly more robust, pluritubulose culms - commonly with only 2 or 3 longitudinal vascular strands - whereas E. jacobsiana has unitubulose culms with a single central vascular strand. It does not seem to develop the numerous filiform sterile culms seen in E. jacobsiana. It differs from E. ochrostachys most obviously in the shape of the epidermal cells on the achene: isodiametric, versus strongly transversely linear-oblong in E. ochrostachys.

Notes: referred to as 'Eleocharis sp. A' by Rye (1992; fig. 310M), as Eleocharis sp. A Kimberley Flora (W.V.Fitzgerald 1038)' on the FloraBase website (http://florabase.dec. wa.gov.au; accessed 17 October 2010), and as 'Eleocharis (Nourlangie Creek entity)' by Cowie (2000, fig. 58) and Hinchliff and Roalson (2009).

This species differs from all of the other relatively slender Australian species in subgenus Limnochloa by the following combination of characers: terete, pluritubulose culms; sterile filiform culms absent; an achene with a short but distinct neck and with the epidermal cells isodiametric; perianth bristles shorter than the body of the achene.

The sister taxon to E. rivalis in the molecular analysis by Hinchliff and Roalson (2009; named there as E. sp. 'Nourlangie Creek entity') is E. sanguinolenta (there named as Eleocharis sp. 'Beatrice Hill entity'). This is somewhat unexpected since these two species are not particularly similar morphologically: E. rivalis is a slender species with pale green to pale yellow-brown glumes whereas E. sanguinolenta is a robust species with conspicuous reddish glumes. Perianth bristle and achene features also differ.

These two species group at the next level in the molecular analysis with E. nuda C.B.Clarke, E. sp. aff. nuda (refers to E. keigheryi; Eric Roalson, pers. comm.), E. triquetra (as E. sp. 'Lansen Creek entity' there) and E. brassii as part of Clade A. The first three of these species are relatively slender like E. rivalis, while E. brassii is more robust. E. rivalis differs most obviously from E. triquetra in culm cross-section (terete in the former, triquetrous and slightly winged in the former). It differs from E. nuda in bristle and achene features.

The internal culm structure of very slender culms of E. rivalis may be hard to distinguish from slender culms of E. jacobsiana, but the species are clearly distinguishable on other features such as the glumes, bristles and achenes. 




Fig. 4. Holotype of Eleocharis rivalis. 
E. rivalis has been compared by me and others (see, for example, Rye 1992) to E. variegata (Poir.) Presl, which is a rather variable species of similar size widespread in Africa and South and SE Asia (Kern 1974). It differs from that species most obviously in features of the achene. The achenes are about the same size but the persistent stylebase is slightly larger in E. rivalis. The achene has a short but obvious neck in E. rivalis with the annulus above that thickened and obvious, whereas in E. variegata the achene has no neck and the annulus is a thin line. The surface of the achene in E. rivalis has the epidermal cells pitted and in 12-18 columns, whereas the cells are somewhat larger and inflated or convex and in 12-15 columns in E. variegata.

Etymology: From the Latin adjective rivalis, $-e$, 'of a brook', referring to the common occurrence of this species in and beside small running streams.

Selected specimens examined: Western Australia: Fitzgerald: Traine River, 'Tableland' [now 'Yulumbu'], S.W.L. Jacobs 4366, 1 Jun 1982 (NSW). Gardner: 2 km W of Kalumburu, I.D. Cowie 4245 \& C.L. Brubaker, 24 May 1993 (DNA, NSW); Isdell River near Mt Barnett Homestead, W.V. Fitzgerald 1038, Jun 1905 (PERTH); King Edward River, S.W.L. Jacobs 5824 \& P.G. Wilson, 1 Jun 1988 (NSW); Vansittart Bay, SE corner - Pauline Bay, J.H. Willis s.n., 25 May 1984 (MEL); 6 km N of Kalumburu on Pago road, K.L. Wilson 10098, 3 Jul 2002 (NSW, NE, PERTH, WS); Black Rock Pool, c. 30 km NW of Kununurra on Parry Lagoons road, K.L. Wilson 10144, 6 Jul 2002 (NSW, PERTH); Augustus Island, Bonaparte Archipelago, P.G. Wilson with [sic]10873, 18 May 1972 (PERTH).

Northern Territory: Darwin \& Gulf: About SSE of Adelaide River, S.T. Blake 16457, 13 Jul 1946 (BRI, NSW); about SSE of mouth of Daly River, S.T. Blake 16607, 24 Jul 1947 (BRI); N of Nutwood Downs HS., at Flick Waterhole, S.T. Blake 17574, 1 May 1947 (BRI); Delamere Station, I.D. Cowie 9164 \& C.R. Michell, 2 May 2001 (DNA, NSW); Gimbat Creek, C.R. Dunlop 7124 \& P.F. Munns, 24 Oct 1987 (DNA, MEL, NSW); Edith Falls, P.K. Latz 3106, 3 Jul 1972 (DNA, BRI, CANB); c. 40 km SSW of Nathan River Homestead, P.K. Latz 10153, 28 Aug 1985 (NSW, NT); Vanderlin Island, P.K. Latz 10698, 22 Jul 1988 (DNA, NSW); Fitzmaurice River headwaters, P.K. Latz 13849, 12 May 1994 (DNA, NSW); c. 35 miles [56.3 km] NNE of Pine Creek township, M. Lazarides $221 \&$ L. Adams, 13 Mar 1965 (CANB, BRI, E, K, L, NSW, NT, US); 66 km from Pine Creek, on road to Jabiru, G.J. Leach 536, 5 Mar 1985 (DNA, NSW); Kakadu National Park, Birdie Creek, G.J. Leach 2734 \& I.D. Cowie, 18 Apr 1990 (DNA, NSW 284819); Hades Flat Meteorological Station, c. 4 km SSE of Ja Ja Camp, K.L. Wilson 5160 \& N. Sanderson,

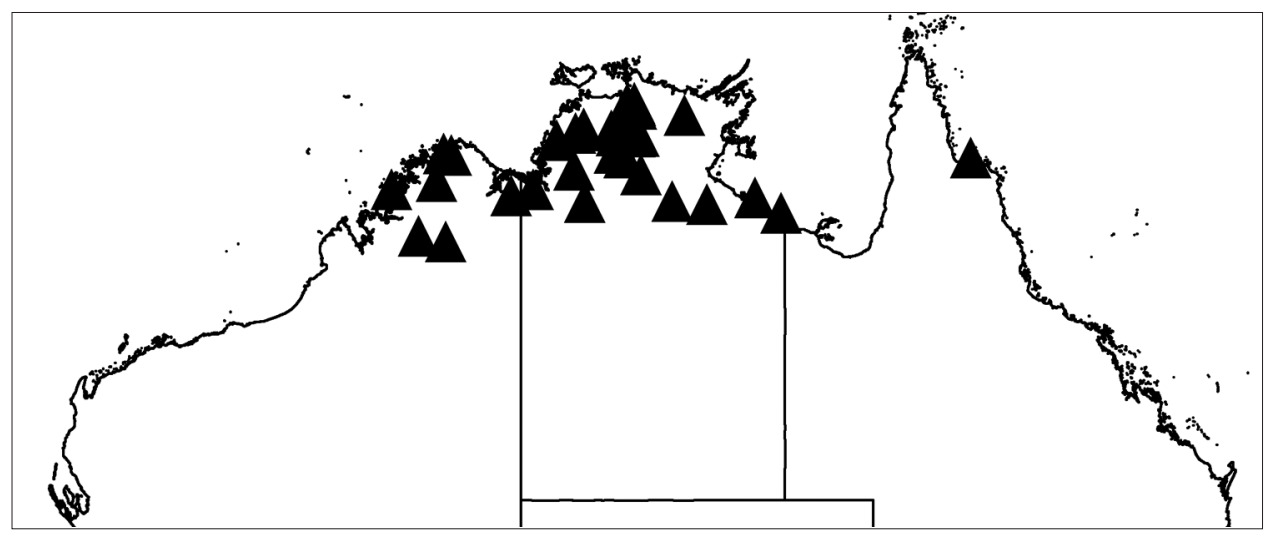

Fig. 5. Distribution of Eleocharis rivalis in northern Australia. 
6 May 1983 (NSW); Plumtree Creek, 3 km SW of South Alligator crossing on Pine Creek El Sharana road, K.L. Wilson 5248, 9 May 1983 (NSW); Gulungul Creek, road between Jabiru and East Jabiru, K.L. Wilson 7218, 15 May 1987 (NSW); Barramundie Gorge, K.L. Wilson 7300, 20 May 1987 (NSW); Magela Creek, c. 2 km downstream from Gulungul Billabong, K.L. Wilson 7353, 22 May 1987 (NSW); Katherine Gorge National Park, Katherine Gorge, above Lily Pond, K.L. Wilson 7531, 5 Jun 1987 (NSW).

Queensland: Cook: Laura Station, N. Byrnes 3450, 21 May 1975 (BRI).

\section{Eleocharis sanguinolenta K.L.Wilson, sp. nov.}

$\mathrm{Ab}$ E. brassiiglumis sanguineis apicem versus plus minusve planis, habitu robustiore, setis perigonialibus quam acheniis longioribus, differt. Ab E. sundaica glumis longioribus, minus obtusis, minus confertis, cellulis epidermalibus achenii isodiametris vel parum transverse elongatis, differt.

Type: Northern Territory: Darwin \& Gulf: 'Kapalga' Landing, K.L. Wilson 5135, 5 May 1983; holo NSW 267685; iso BRI, DNA, K, MO, PERTH. Figure 6.

Robust perennial, with slender stolons, without tubers so far as known. Culms erect, tufted, terete, tend to be flattened when dry, mid-yellow-green, pluritubulose, 35-90(-150) cm high, 3.5-7 $\mathrm{mm}$ diam. Upper leaf sheath membranous, very pale brown above, dark red-brown towards base, with strongly oblique apex not thickened or differently coloured. Spikelet terete or slightly angular in cross-section, as broad as to slightly broader than the culm, 2-5 cm long, 4-7 $\mathrm{mm}$ diam. Glumes numerous, striate, with a fairly distinct midnerve, with apex broad-acute to obtuse, flat to slightly convex when dry, red-brown above, pale yellow-brown below at maturity, often with a darker red line just inside the narrow $(0.2-0.3 \mathrm{~mm}$ wide) hyaline margin, $4.5-5.5 \mathrm{~mm}$ long, (2.0-)2.5-3.5 mm broad; exposed portion of glume longer than broad or as long as broad, 2-3.5 mm long. Perianth bristles 6 or 7, of about equal length, 1.2-1.5 times as long as achene body, brown, with inflated and blunt irregularly retrorse setae. Stamens 3; anthers (excluding apical appendage) 1.0-3.0 mm long; appendage no more than $0.1 \mathrm{~mm}$ long. Style 2 -fid; persistent style-base flattened, triangular, $1 / 3-3 / 4$ as long as achene, $2 / 3-3 / 4$ as broad as achene. Achene biconvex, broad-elliptical to broad-obovate in outline, margins not ribbed, without a distinct neck or sometimes a very short one and with the annulus a thickened band upturned at the margins and convex centrally, achene grey green to very dark brown, 1.5-2.0 mm long, 1.2-1.8 mm diam., epidermal cells often isodiametric at centre of a face but otherwise shortly transversely elongated, thin-walled, slightly pitted, in 18-22 well-defined columns. Figure 1c

Distribution and ecology: known from the wet/dry tropics of Australia; from the eastern part of the Kimberley Region of Western Australia, east to Victoria River and Darwin and Gulf Regions of the Northern Territory and the Burke and Cook botanical Regions of Queensland. It could possibly also occur in Papua New Guinea and adjoining regions of Indonesia, as does E. sundaica. Figure 7.

In billabongs, floodplains and swamps, to a depth of at least $40 \mathrm{~cm}$ (water depth is commonly not recorded, particularly not the maximum depth at which a species is growing at the height of the Wet Season), usually in clayey soils. It often grows with or near E. dulcis, E. sphacelata and E. sundaica on floodplains, either as a mosaic or in zones based on water depth. On the South Alligator River floodplain at Kapalga, for example, I found E. dulcis (specimen KLW 5133) growing in slightly deeper water 
than E. sanguinolenta (KLW 5135) and E. sundaica (KLW 5134). I am not aware of any detailed studies of the ecology and habitat preferences of these species, but Ian Cowie (pers. comm.) confirms my observations. I have seen this species growing also with E. brassii, E. spiralis (Rottb.) Roem. \& Schult. and E. triquetra.

Notes: This species was referred to as 'Eleocharis sp. B' in Rye (1992; fig. 310N), as 'Eleocharis sp. B Kimberley Flora (K.F. Kenneally 8727)' on the FloraBase website (http://florabase.dec.wa.gov.au; accessed 17 October 2010), and as 'Eleocharis (Beatrice Hill entity)' in Cowie (2000, fig. 58) and Hinchliff and Roalson (2009). Specimens of this have often been labelled as 'E. sp. aff. brassii' by me and others in herbaria.

The species is unusual amongst the Australian species in subgenus Limnochloa in having reddish glumes (at least near the apex), with a narrow darker band near the apex close to the hyaline margin. It differs from the only other species here with reddish glumes, E. sundaica, in having longer glumes that are less densely packed so that the exposed portion of the glumes is longer than broad, while the opposite is true for E. sundaica. This gives the spikelets a very different appearance. In addition, the new species has a different achene surface (epidermal cell outlines being isodiametric or shortly elongated transversely versus markedly and minutely transversely linear-oblong in E. sundaica) and does not produce small tubers so far as known, whereas E. sundaica commonly produces them. A good field difference is that the culms of E. sanguinolenta are more easily compressed between the fingers than those of E. sundaica.

It has often been referred to as ' $E$. sp. aff. brassii', perhaps mostly because of the similar shape and surface patterns of the achenes of this species and E. brassii, but other morphological features are not particularly similar and there is probably no close relationship to that species. Indeed, the sister taxon to E. sanguinolenta in the molecular analysis by Hinchliff and Roalson (2009; there named as Eleocharis sp. 'Beatrice Hill entity') is neither E. brassii nor E. sundaica but rather the new species E. rivalis (named there as E. sp. 'Nourlangie Creek entity'). That is a slender species easily separable morphologically from E. sanguinolenta on size and achene features (the surface and the presence of an obvious neck).

E. sanguinolenta and E. rivalis group at the next level with E. nuda, E. sp. aff. nuda (this is referable to E. keigheryi K.L.Wilson; Eric Roalson pers. comm.), E. triquetra (E. sp. 'Lansen Creek entity' there) and E. brassii. The first three of these species are much more slender than E. sanguinolenta and therefore not be confused with it. It differs from E. brassii in being somewhat more robust, and in having glumes that are often flatter at maturity than the greenish to pale yellow-brown glumes of E. brassii. The shape of the glumes contributes to the more terete cross-section of the new species compared to the rather angular appearance of $E$. brassii because of the more folded, protruding glumes of E. brassii. The perianth bristles of E. sanguinolenta are usually longer than the body of the achene, unlike those of E. brassii, which are usually obviously shorter than the body of the achene.

Etymology: the epithet is from the Latin adjective sanguineus, $-a,-u m$, 'blood-red', and the suffix -lens, -lentus, 'abundant' or 'prone to', referring to the well-developed dark red colour of the upper part of the glumes.

Selected specimens examined: Western Australia: Gardner: Parry Lagoons Nature Reserve, I.D. 


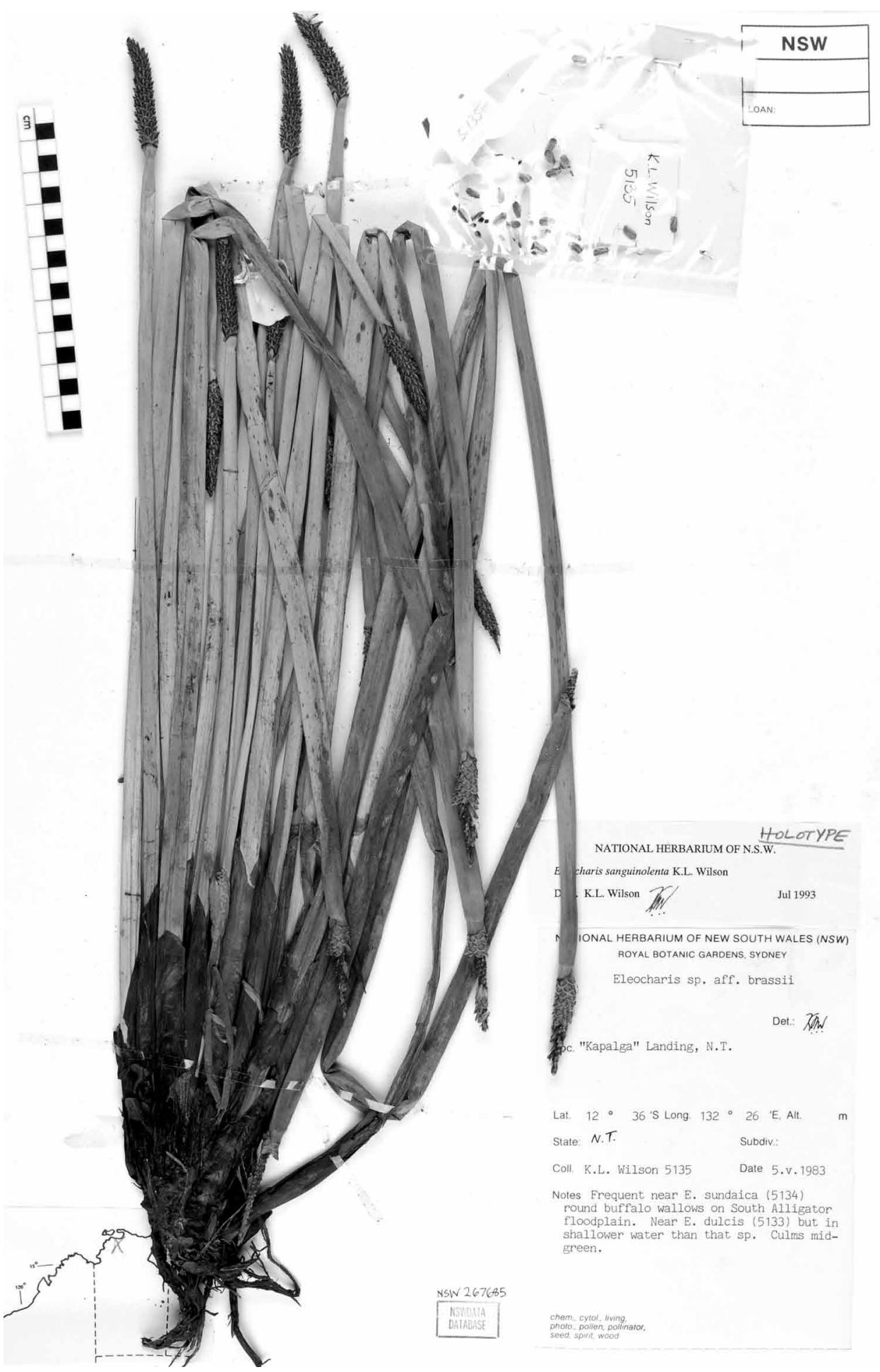

Fig. 6. Holotype of Eleocharis sanguinolenta. 
Cowie 9582, 1 May 2002 (DNA, NSW, PERTH); Ord River, 30 km NW of Kununurra, K. Paijmans 2243, 8 Mar 1978 (CANB, NSW, PERTH); Ord River, 1 km S of Kununurra, K. Paijmans 2295, 10 Mar 1978 (CANB, K, NSW); Packsaddle Plain, 1 km SE of Kununurra Diversion Dam, K.L. Wilson 4844, 4845, 24 Apr 1983 (NSW); Parker Road, just NE of Spillway Creek bridge, Lake Argyle, K.L. Wilson 4892, 26 Apr 1983 (NSW).

Northern Territory: Darwin \& Gulf: $16^{\circ} 25^{\prime}$ S 13459'E, S.T. Blake 17630, 4 May 1947 (BRI); Beatrice Hill, 40 miles [64 km] SE Darwin, G.M. Chippendale 7938, 23 Mar 1961 (NT, NSW); Kapalga, R. Collins BC429, 28 Apr 1977 (DNA); Finniss River floodplain, I.D. Cowie 999 \& G.J. Leach, 27 Mar 1990 (DNA, CANB, NSW); Reynolds River floodplain, I.D. Cowie 1076 \& B. Wilson, 29 Mar 1990 (DNA, NSW); South Alligator River, Arnhem Highway, C. Dunlop 4698, 8 Feb 1978 (DNA, BRI, K, L); Humpty Doo, H.J. Frith s.n., 28 Feb 1956 (NSW 70376); c. $5 \mathrm{~km} \mathrm{~N}$ of Nathan River Station, G.J. Leach 624, 8 May 1985 (DNA, NT, NSW); South Brolga, Tortilla Flat, Upper Adelaide River, A.O. Nicholls 84, Apr 1967 (DNA); Adelaide River, Arnhem Highway, M. Rankin 2265, 17 Apr 1980 (DNA, BRI, CANB); off Rookery Point, Kapalga, J. Taylor 371, 8 May 1981 (BRI); Wadjelai Billabong, N.B. Tindale s.n., May 1921 (NSW 24397); just N of South Alligator River bridge on Pine Creek - El Sharana road, K.L. Wilson 5244, 9 May 1983 (NSW); near Old Munmarlary Abbatoir, K.L. Wilson 7372, 23 May 1987 (NSW); S of Bullocky Point, towards Kapalga Landing, K.L. Wilson 7441, 7449, 28 May 1987 (NSW 196706, 267683); Mary River crossing, Arnhem Highway, K.L. Wilson 7481, 31 May 1987 (NSW). Victoria River: Auvergne Station, King Billabong, Victoria Highway, $2.5 \mathrm{~km}$ W of East Baines River, I.D. Cowie 9594, 3 May 2002 (DNA, NSW); Lower Victoria River, F. $\operatorname{Mueller}(\mathrm{K})$.

Queensland: Burke: Magowra Station, L. Craven 4779, 18 July 1977 (CANB); Harris Lake, 9 km SE of Burketown, K.L. Wilson 5573, 20 May 1983 (NSW). Cook: Lakefield National Park, 16 km from Jam Tin Creek on track from Bizant to Jane Table Hill, J.R. Clarkson 6968 \& B.K. Simon, 6 May 1987 (MBA, QRS, NSW); Swan Swamp on the Dunbar to Rutlands Plains road, Cape York Mapping site 438 (KOW 4), J.R. Clarkson 9420 \& V.J. Neldner, 20 May 1992 (MBA, NSW); near Norman River on Croydon road, K. Paijmans LAC 4846, 21 Jul 1977 (CANB); Laura River, c. 35 $\mathrm{km} \mathrm{N}$ of Laura, in swamp c. $1 \mathrm{~km} \mathrm{~W}$ of river, M. Thorsborne 371, 7 Jun 1977 (BRI).

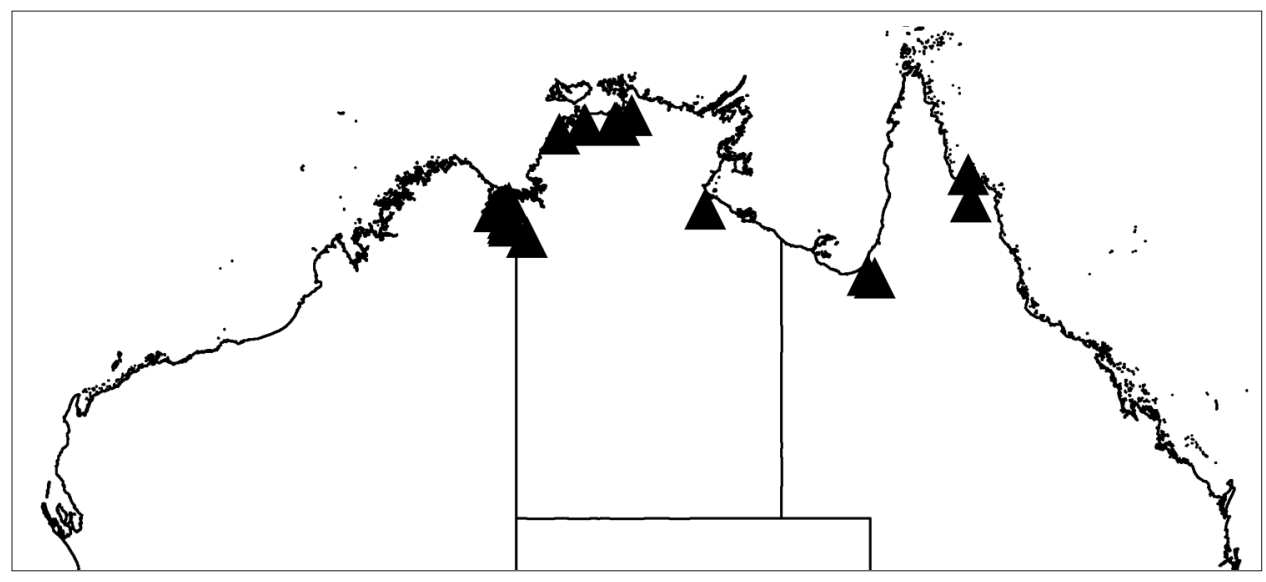

Fig. 7. Distribution of Eleocharis sanguinolenta in norhern Australia. 


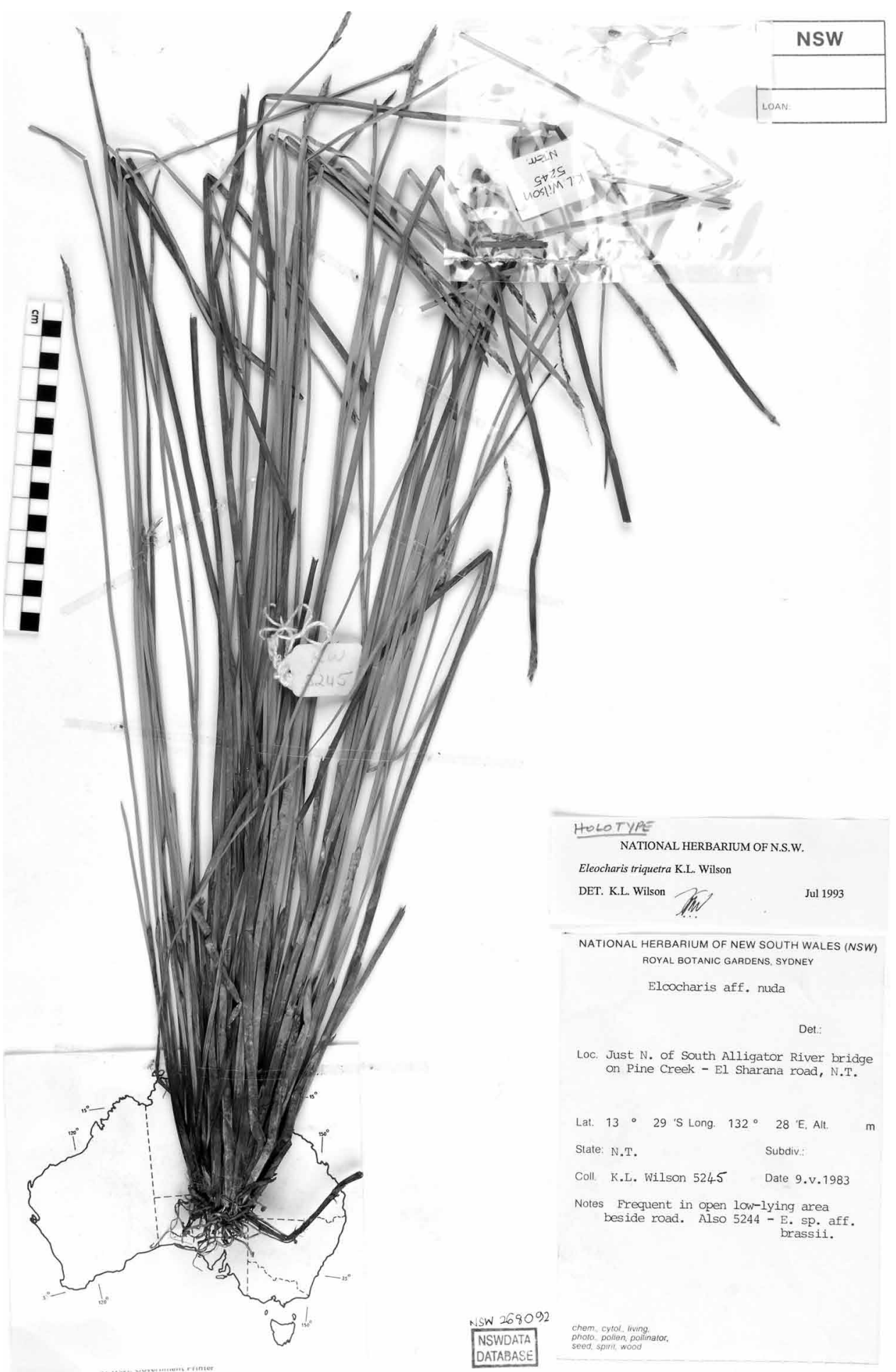

Fig. 8. Holotype of Eleocharis triquetra. 


\section{Eleocharis triquetra K.L.Wilson, sp. nov.}

E. nuda affinis, sed culmo triquetro semi-alato, setis perigonialibus plerumque persistentibus, glumis antherisque longioribus, differt.

Type: Northern Territory: Darwin \& Gulf: just N of South Alligator River bridge on Pine Creek - El Sharana road, K.L. Wilson 5245, 9 May 1983; holo NSW 268092; iso: DNA, K, NSW 867245, PERTH. Figure 8.

Slender annual or perennial with slender stolons, without tubers so far as known. Culms erect, tufted, sharply triangular, slightly winged on angles, yellow-green, pluritubulose, smooth or with incomplete transverse septa faintly visible when dry, 30-55(-70) cm high, 1.0-3.0 mm diam. Upper leaf sheath membranous, pale brown, often reddish towards base, rarely dark reddish towards apex, with strongly oblique apex not thickened or differently coloured. Spikelet terete in cross-section, slightly broader to slightly narrower than the culm near the apex, (1.5-)2-5 cm long, 1.8-2.5 mm diam. Glumes numerous, striate, with midnerve indistinct abaxially, more or less concave to flat when dry, with broad-acute to obtuse apex, green to pale yellow-brown, occasionally with a darker narrow brown band at the apex, 3.7-4.5 $\mathrm{mm}$ long, (1.5-)2.0-2.5 mm wide, with broad hyaline margin $0.2-0.4 \mathrm{~mm}$ wide, exposed portion of glume longer than wide, $3.0-4.0 \mathrm{~mm}$ long. Perianth bristles $2-5$, subequal or 1 or 2 bristles longer, $1 / 6-1 / 3(-2 / 3)$ as long as achene body, occasionally very reduced (c. $0.2 \mathrm{~mm}$ long), brown, with or without strongly retrorse setae. Stamens 2; anthers (excluding apical appendage) $0.5-1.3 \mathrm{~mm}$ long; appendage no more than $0.1 \mathrm{~mm}$ long. Style 2-fid; persistent style-base flattened, short-triangular, $1 / 4-1 / 2$ as long as achene, $1 / 2-2 / 3$ as broad as achene, or occasionally very reduced in size. Achene biconvex, more or less obpyriform, broad-elliptical to broad-obovate in outline, margins ribbed, with short but distinct neck and with the annulus upturned at the margins, achene pale yellow-brown to black or grey-brown with blackish pits, $1.3-1.6 \mathrm{~mm}$ long, $1.0-1.4 \mathrm{~mm}$ diam., epidermal cells isodiametric, thin- to thick-walled, in 12-16 more or less regular columns. Figure 1d.

Distribution and ecology: widespread, but apparently not common anywhere, in the Victoria River and Darwin and Gulf Regions of the Northern Territory; known from Western Australia by a single specimen from near Kununurra in the eastern

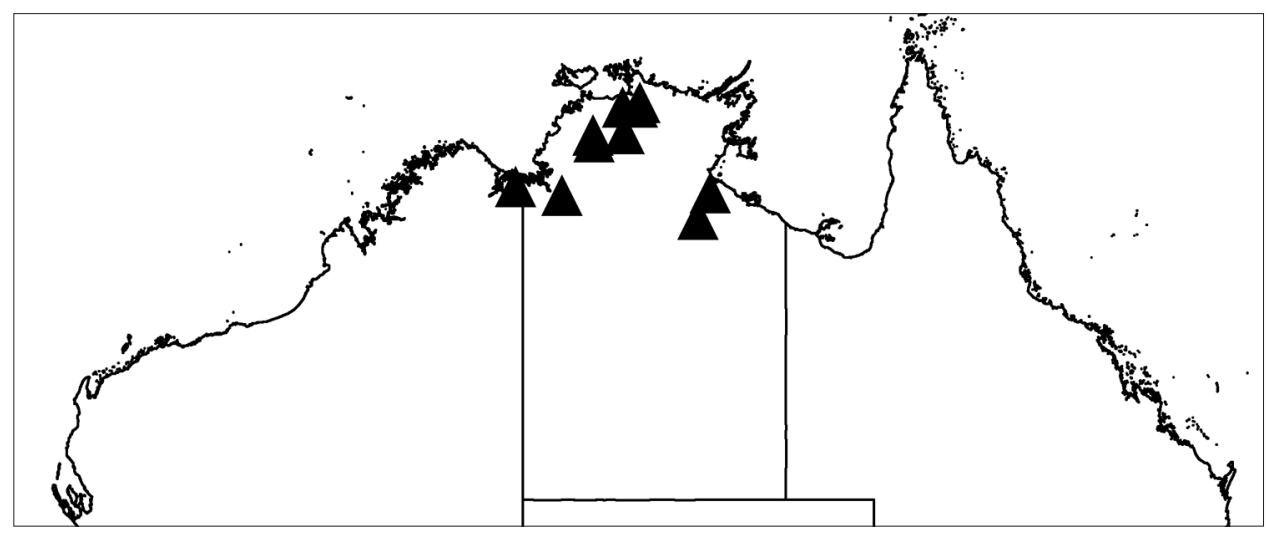

Fig. 9. Distribution of Eleocharis triquetra in northern Australia. 
Kimberley. It might also occur in northwestern Queensland around the base of the Gulf of Carpentaria. It could possibly occur in adjoining regions of New Guinea and Indonesia, as does E. sundaica. Figure 9.

In seasonally wet situations such as shallow pools and Melaleuca swamps, collected on muddy banks or in water to $30 \mathrm{~cm}$ deep, in clayey soils. Found growing with E. sundaica ( $K L W$ 5011) in the Top End of the Northern Territory, in shallower water than that species, and with E. nuda (Cowie 9943).

Notes: referred to as 'Eleocharis (Lansen Creek entity)' by Cowie (2000, fig. 58) and Hinchliff and Roalson (2009) and as 'sp. aff. acutangula (S.T. Blake 17630)' on herbarium specimens in DNA.

It differs from the other relatively slender Australian species in this subgenus in having triquetrous, slightly winged culms (terete or $4-5$-angled in the other species). The other relatively slender, angular-culmed Australian species is E. philippinensis Svenson, which has culms that are 4-5-angled in cross-section. E. triquetra further differs from E. philippinensis in having 2 stamens ( 3 in the latter), perianth bristles fewer $(2-5$ in the former versus 6-7 in the latter) and much shorter than the achene body (from half as long as to equalling the body in the latter), and an achene that has fewer columns of cells per face and an annulus that is concave/upturned at the margins (flat in E. philippinensis).

Apart from the culm shape (and the often more robust culms), it is morphologically closest to E. nuda. The glumes are larger in E. triquetra (3.5-4.5 $\mathrm{mm}$ long and usually 2.0-2.5 mm wide, versus 3.0-3.8 $\mathrm{mm}$ long and $1.5-2.0 \mathrm{~mm}$ wide in E. nuda), and the anthers are longer in E. triquetra (1.0-1.4 mm long versus 0.2-0.6 $\mathrm{mm}$ long in E. nuda). The achenes are similarly more or less obpyriform in shape, but the cell outlines on the surface are mostly thinner-walled in E. triquetra, while the perianth bristles are persistent and short (reduced to about $0.2 \mathrm{~mm}$ occasionally) or rarely deciduous (e.g., in Cowie 9942), whereas in E. nuda they are nearly always very reduced and deciduous at a very early stage. These morphological differences are not great, but there are no clear geographic or habitat differences to suggest that the new taxon might better be treated as a subspecies of E. nuda. Their ranges overlap in the Northern Territory, and they have been collected in the same locality at least once (Cowie 9942 and 9943, from a seasonal lagoon on Cave Creek Station).

It has been named on some specimen labels as 'sp. aff. acutangula' but its resemblance to the slightly more robust E. acutangula (Rox.) Schult. is superficial, based on both having triquetrous, more or less winged culms. The two species differ in all other significant features.

It groups with E. nuda, E. sp. aff. nuda (referable to E. keigheryi; Eric Roalson pers. comm.) and E. brassii in the analysis by Hinchliff and Roalson (2009), but the relationships are less resolved than others in the study. It differs from E. brassii in being less robust than that species as well as differing in glume, bristle and achene features. It differs from E. keigheryi, a relatively slender species from southwestern Australia, most obviously in the epidermal cell outlines on the achene: isodiametric in E. triquetra and transversely linear-oblong in E. keigheryi.

Etymology: from the Latin adjective triquetrus, $-a,-u m$, sharply three-angled, referring to the cross-sectional shape of the culms, which are sharply angled and slightly winged on the angles. 
Selected specimens examined: Western Australia: Fitzgerald: c. $4 \mathrm{~km} \mathrm{~N}$ of Napier Range on Gibb River road, K.L. Wilson 10068, 28 Jun 2002 (NSW, PERTH). Gardner: East Packsaddle Swamp, Kununurra, K. Brennan s.n., 24 Mar 1980 (NSW 268086).

Northern Territory: Darwin \& Gulf: Kapalga, R. Collins 429, 28 Apr 1977 (DNA); 16²5'S 134 59'E, S.T. Blake 17630, 4 May 1947 (BRI); Cave Creek Station, lagoon 5.2 km SW of Moray Hill, I.D. Cowie 9942, 21 Mar 2003 (DNA, BRI, NSW); Limmen National Park, c. 4 km NW of Cox River crossing, I.D. Cowie 11984, 20 Apr 2008 (DNA, NSW); Bing Bong Station, P.K. Latz 1481, 7 Jun 1971 (NSW); c. 5 km N of Nathan River Station, G.J. Leach 612, 8 May 1985 (DNA, NT, BRI, CANB, L, MO, NSW); $20 \mathrm{~km} \mathrm{~W}$ along Arnhem Highway from Oenpelli road turnoff, N.T. Sanderson s.n., 7 May 1981 (UNSW, NSW 268087, 268088); Douglas Hot Springs Nature Park, K.L. Wilson 4998, 29 Apr 1983 (NSW); 17.5 km SW of old Stuart Highway on Oolloo road, K.L. Wilson 5012, 29 Apr 1983 (NSW). Victoria River: Victoria Highway, 16.5 km W of Timber Creek Police Station, I.D. Cowie 9599, 3 May 2002 (DNA, NSW).

\section{Acknowledgments}

This study was partly funded by grants from the Australian Biological Resources Study to me in 1992-94 for broader studies in Eleocharis and Rhynchospora. My thanks go to Kristina McColl for her very capable technical assistance during that period, also to Dianne Godden for taking the SEM images of achenes of these species and to Debby McGerty for scanning them. I am grateful for the helpfulness of John Taylor (then with CSIRO), Clyde Dunlop and Ian Cowie (DNA), and Max Finlayson and Kym Brennan (both then with the Office of the Supervising Scientist at East Jabiru) with fieldwork, particularly on the Kapalga and Magela floodplains. Ian Cowie and Eric Roalson are thanked for their comments on various matters, and the following Herbaria are thanked for either sending specimens on loan or making their facilities available to me when visiting: $\mathrm{AD}, \mathrm{BM}, \mathrm{BRI}, \mathrm{CANB}, \mathrm{DNA}, \mathrm{G}, \mathrm{HO}, \mathrm{K}, \mathrm{L}, \mathrm{LD}, \mathrm{MEL}, \mathrm{NE}, \mathrm{NT}$, NY, P, PERTH, US.

\section{References}

Blake ST (1939) A monograph of the genus Eleocharis in Australia and New Zealand. Proceedings of the Royal Society of Queensland 50(12): 88-132, pls VII-X.

Buchenau F (1890) Monographia Juncacearum. (W. Engelmann: Liepzig)

Cowie ID (2000) Eleocharis R.Br. Pp. 251-259 in Cowie ID, Short PS \& Osterkamp Madsen M, Floodplain Flora: A flora of the Coastal Floodplains of the Northern Territory. (Flora of Australia Supplementary Series no. 10)

Fernández-Carvajal MC, Garcia R \& Díaz-Gonzales TE (1989) Clave para la identificacion de las especies ibericas del genero Juncus L. basada en caracteres anatomicos. Acta Botanica Malacitana 14: 89-104.

Govaerts R, Simpson DA, Bruhl JJ, Egorova T, Goetghebeur P \& Wilson K (2007) World Checklist of Cyperaceae. Sedges. 765 pp. (Royal Botanic Gardens: Kew)

González-Elizondo MS \& Tena-Flores JA (2000) Eleocharis (Cyperaceae) in the New World. Pp. 637-643 in Wilson KL \& Morrison DA (eds), Monocots: Systematics and Evolution. (CSIRO Publishing: Collingwood)

Hinchliff CE \& Roalson EH (2009) Stem architecture in Eleocharis subgenus Limnochloa (Cyperaceae): Evidence of dynamic morphological evolution in a group of pantropical sedges. American Journal of Botany 96: 1487-1499.

Hinchliff CE, Petersen S \& Roalson EH (2010) Eleocharis endounifascis: A new species of Eleocharis subgenus Limnochloa (Cyperaceae) from northern South America. Phytotaxa 7: 19-24. 
Kern JH (1974) Cyperaceae. Flora Malesiana, series 1, vol. 7(3). (Noordhoff International Publishing: Leyden)

Kirschner J (compiler) (2002) Species Plantarum - Flora of the World Parts 6-8, Juncaceae. (ABRS: Canberra)

Rye BL (1992) Cyperaceae. Pp. 1035-1107 in Wheeler JR, Rye BL, Koch BL \& Wilson AJG, Flora of the Kimberley Region. (Dept of Conservation and Land Management: Perth)

Snogerup S (1980) Juncus. Pp. 102-111 in Tutin TG et al. (eds), Flora Europaea, vol. 5. (Cambridge University Press: Cambridge)

Wilson KL, Johnson LAS \& Bankoff P (1993) Juncus. Pp. 266-289 in Harden GJ (ed.) Flora of New South Wales, vol. 4. (University of NSW Press: Sydney)

Manuscript submitted 17 September 2010, accepted 21 October 2010 